DOI: https://doi.org/10.15407/preislamic2021.02.033

UDC 94(3):295.48

\title{
AVESTAN TAŠTA-BOWL IN THE IRANIAN TRADITION: ORIGINS AND REMINISCENCES
}

\author{
H. V. Vertiienko \\ $\mathrm{PhD}$ (History) \\ A. Yu. Krymskyi Institute of Oriental Studies, NAS of Ukraine \\ 4, Hrushevskoho Str., Kyiv, 01001, Ukraine \\ vertana77@gmail.com
}

In the Zoroastrian tradition, the ritual libation bowl is tašta (Visperad $10.2=11.18$ ). It is a bowl for the haoma (Videvdat 14.8; Yasna 10.17), due to which it becomes an attribute-weapon of both the priests and Zarathushtra (Videvdat 14.8; 19.9). A wide range of materials from which it could be made is given in Videvdat 7.73-75: gold, silver, bronze (iron), steel (?), stone, earth (?), wood and clay, and the last three types of bowls can not be cleaned. Yasna 10.17 allows silver and gold bowls in the ritual of haoma preparation. By etymology, tašta was a part of the original IndoEuropean semantic circle of objects made (carved) of wood. Despite the fact that the Vedic tradition has retained a number of names of wooden vessels associated with the cult of soma (including metaphorical names) camasâ, the first wonderful wooden bowl for soma made by the divine carpenter Twashtar (Rigveda I.20.6), is probably comparable to the ancient Iranian tašta. Among the early Iranian-speaking nomads of Eurasia, the closest to tašta and camasâ can be recognized as wooden libation bowls with metal (gold, silver and bronze) plates, which have been known in the Northern Black Sea region since the Bronze Age (Timber Grave Culture). Among the Iranianspeaking nomads of Eurasia, remote from India and Iran due to migration processes, an original tradition of decorating wooden cult bowls with metal plates has apparently developed, which combines features of Indian and Iranian traditions. Perhaps this type of vessel was meant by Herodotus, who defined ritual bowls among the Scythians as pró $\lambda \eta v$ (Herod. Hist. IV.5.3, 10.1, 71.4), i.e. as a typologically similar vessel. At the same time, the Scythians apparently did not allow the use of imported bowls in the cult of sacred drink.

Keywords: Iran, Zoroastrian tradition, Avesta, ritual, libation bowl, tašta, haoma

\section{Г. В. Вертієнко}

\section{АВЕСТІЙСЬКА ЧАША-ТАร̌ТА В ІРАНСЬКІЙ ТРАДИЦЇ̈: ВИТОКИ ТА РЕМІНІСЦЕНЦІї}

Передумовою для цієї статті стала дискусія серед археологів, який вид посуду іраномовних номадів Свразійського степу слід ототожнювати з ритуальними чашами, пов'язаними з культом священного напою соми/хаоми. Наявність подібного культу серед нащадків індоарійців $є$ маркером того, що і в давніх кочових іраномовних народів подібний культ не міг не існувати. Це спонукає звернутися до іранської традиції, а саме до корпусу Авести, де єдиним посудом для ритуального узливання, що фігурує в контексті культу хаоми, є 'чаша' tašta.

Розглянемо контекстуальне застосування цієї лексеми (табл. 1). Це слово фіксується в єдиній Ясні (10.17), двічі у Віспераді $(10.2=11.18)$ і в чотирьох фрагардах Відевдату $(5,7,14,19)$. У Гатах це слово відсутнє, що можна пояснити свідомим уникненням пророком Заратуштрою згадок хаоми та пов'язаних 3 цим 
напоєм предметів і ритуалів (Ясна 32.14; 48.10) [Flattery, Schwarz 1988, 105-116; Kellens 1995, 730; Schwarz 2006, 215-224]. Відсутність tašta в Яштах може мати різні пояснення, зокрема те, що цей посуд не атрибутує жодне з божеств, шанованих у цих гімнах. Натомість максимально це слово представлено у жрецькому кодексі Відевдаті, який пов'язаний з питаннями ритуальної чистоти.

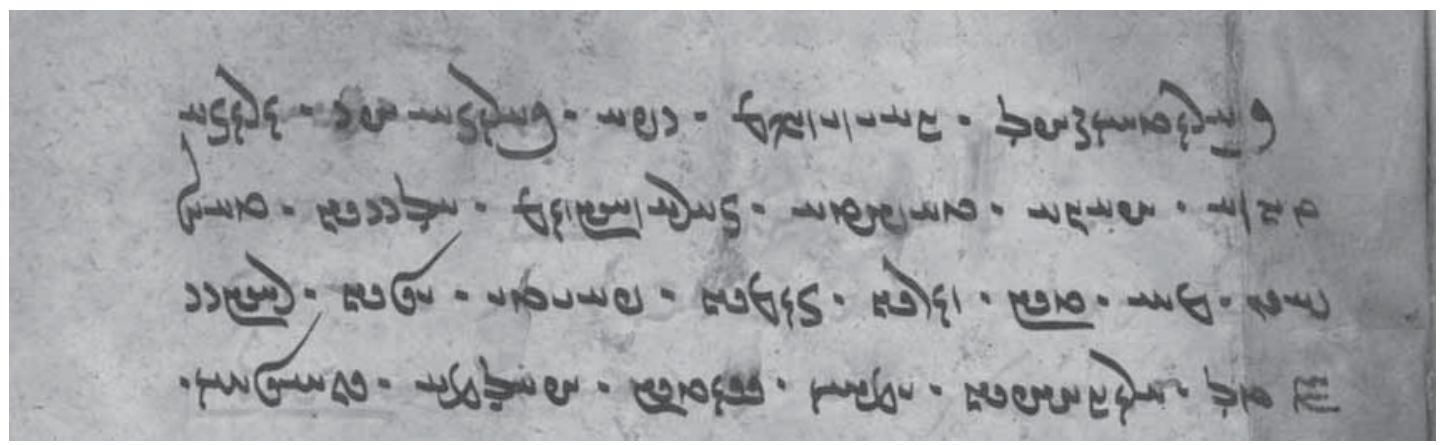

Мал. 1. Фрагмент Ясни $17.10^{1}$ за рукописом 4000_TU1 (Tehran University Library nr. 11263) (C) Avestan Digital Archive)

Ясна 10.17 містить молитву Заратуштри хаомі, де проголошується, що він переливає священний напій зі срібної чаші-tašta в золоту² (мал. 1). У Віспераді (10.2 i рефрен 11.18) наведено частину молитви, яку вимовляє священнослужитель перед літургійними інструментами, де уточнюється, що tašta призначена для узливання. Відевдат 5 у параграфах 39 і 40 подає інформацію, як слід чинити з чашами, якщо в будинку померла людина або собака. Тут немає уточнення, що це чаша для узливання, як у попередніх джерелах, але контекст вживання разом з хаомою на це вказує.

7-й фрагард Відевдату, який спрямовано проти демона Друхи-йа-Hacy, дає рекомендації, пов'язані з очищенням чаш-tašta, виготовлених з різних матеріалів, після їхнього зіткнення з мертвою (нечистою) субстанцією (7.73-75). У тексті наведено відомості, як очистити чаші із золота, срібла, бронзи, заліза, каменю, також ідеться про марність проведення очисного обряду над чашами, які зроблені із землі, дерева і глини. Зокрема, ‘золоті' чаші йдуть у переліку першими і потребують відповідного одноразового очищення. Наступні (чаші) 'срібні' - дворазового, 'бронзові' - триразового, і так далі. Наскільки ця градація матеріалів зустрічалась у віруваннях інших іранських народів, залишається лише здогадуватися, як і щодо того, наскільки наявність глиняного і дерев'яного посуду в похованнях іраномовних номадів могла бути наслідком неможливості його подальшого використання.

При описі знарядь жерця у фрагарді 14.8 після перелічення усіх посудин (для молока, для води, посудини для змішування і ступки) названа саме чаша для хаоми (tašta haomiia). У Відевдаті 19.8-9 tašta виступає однією з чотирьох видів зброї Заратуштри для захисту від Ангра Манью та його створінь. Якщо звернути увагу, з яким арсеналом виступає Заратуштра проти Злого Духа (Ангра Маньї), то стає

${ }^{1}[\ldots]$ araza/tīna haca tašta zaranaēnəm aōuue tax/še mā tē nore zame paiti i७e raēuu/ṇtō arajahe Переклад див.: табл. 1.

${ }^{2}$ Цей пасаж відображає певний бік ритуалу, пов’язаного 3 переливанням. Пор.: [Kotwal, Boyd 1991, 14; 45, pl. 5; 55, pl. 15]. 
Авестійська чаша-tašta в іранській традиції: витоки та ремінісценції

очевидно, що два приладдя, ступка (hāunana) і чаша (tašta), необхідні для отримання священного напою i, отже, з третьою зброєю, хаомою, вони утворюють триєдність. Тож, по суті, зброєю Заратуштри в цьому джерелі є Слово, сказане Маздою, яке промовляється під дією священного напою.

Табл. 1. Чаша (tašta) в текстах Авести

\begin{tabular}{|c|c|c|}
\hline 1 & $\begin{array}{l}\text { Ясна } \\
10.17 \\
\end{array}$ & $\begin{array}{l}\text { <...> Зі срібної чаші у золоту переливаю. } \\
\text { Не пролити мені його додолу, оскільки це велика цінність. }\end{array}$ \\
\hline $\begin{array}{l}2 \\
3\end{array}$ & $\begin{array}{l}\text { Вісперад } \\
10.2= \\
11.18\end{array}$ & $\begin{array}{l}\text { (Я) збираюся віддати хвалу з кам’яною ступкою (і товкачем), із залізною ступ- } \\
\text { кою (і товкачем), із чашею для узливання, із ситечком з волосу для проціджуван- } \\
\text { ня хаоми <..>. }\end{array}$ \\
\hline $\begin{array}{l}4 \\
5\end{array}$ & $\begin{array}{l}\text { Відевдат } \\
5.39 \\
40\end{array}$ & $\begin{array}{l}\text { (39) - О Творцю плотського світу, праведний! Приносимо ми в будинок, о пра- } \\
\text { ведний Ахуро-Маздо, у цьому житті плотський вогонь, барсман, чаші, хаому, да- } \\
\text { вила, а після цього в цьому будинку помре людина або собака, - що мають роби- } \\
\text { ти маздаяснійці? } \\
\text { (40) - Нехай винесуть з цього будинку, о Спітамо Заратуштро, і вогонь, і барс- } \\
\text { ман, і чаші, і хаому, і давила, нехай винесуть мертвого <...>3. }\end{array}$ \\
\hline 6 & $\begin{array}{l}\text { Відевдат } \\
7.73-75\end{array}$ & $\begin{array}{l}\text { (73) <...> як ці чаші, призначені для вживання їжі, очищувати? (74) < ..> якщо } \\
\text { вони золоті, слід один раз промити сечею бика, один раз землею наповнити, один } \\
\text { раз водою промити. Так очищувати. } \\
\text { (75) Але якщо вони срібні, слід двічі промити сечею бика, двічі землею наповни- } \\
\text { ти, двічі водою промити. Так очищувати. Але якщо вони бронзові (залізні), слід } \\
\text { тричі промити сечею бика, тричі землею наповнити, тричі водою промити. Так } \\
\text { очищувати. <...> Але якщо вони земляні, дерев'яні, глиняні - назавжди нечисті. }\end{array}$ \\
\hline 7 & $\begin{array}{l}\text { Відевдат } \\
14.8\end{array}$ & $\begin{array}{l}\text { Всіма знаряддями жерця для чоловіків праведних по істині, по благу заради душі } \\
\text { нехай понесе покарання, з яких знаряддя жерця: батіг, посудина для молока, } \\
\text { паіті-дана (paiti-dāna-), “убивця храфстра”, [батіг, “той-що-робить слухняним”, } \\
\text { посудина для води, посудина для змішування, ступка (що складається з двох час- } \\
\text { тин), як треба зроблена, чаша для хаоми і барсман }{ }^{4} \text {. }\end{array}$ \\
\hline 8 & $\begin{array}{l}\text { Відевдат } \\
19.8-9\end{array}$ & $\begin{array}{l}\text { (8) Йому заперечив злочинний Анхра-Манью: “Чиїм словом поб’єш, чиїм сло- } \\
\text { вом проженеш, якою зброєю [поб’єш?] мої створіння, [створені мною], Анхра- } \\
\text { Манью?” (9) Йому сказав Спітама-Заратуштра: “Ступкою, чашею, хаомою і сло- } \\
\text { вом, сказаним Маздою! Ось моє зброя, найкраща! Цим словом вражу, цим сло- } \\
\text { вом вижену, цією зброєю [вражу?] твої створіння, о злочинний Анхра-Манью! } \\
\text { Створив [цю зброю] Святий Дух, створив [він іiі] в безмежний час, створили [іi] } \\
\text { Амеша-Спента, благовладні, благодійні”. }\end{array}$ \\
\hline
\end{tabular}

У лексиці зороастрійців Індії відомо декількох типів культового посуду, який застосовується в релігійній практиці і пов'язаний, зокрема, 3 приготуванням хаоми. Авестійські найменування посудин tašta (чаша) i häuиana (ступка 3 товкачем) ${ }^{6}$ збереглися, але tašta стала позначати інший тип посуду - "блюдце” [Bartholomae 1904, 646 ('Tasse, Schale'); Kotwal, Boyd 1991, 34-35, fig. 4; 144]7. Для позначення “чаші” нині використовується слово fuliyān (парс. гудж.) [Kotwal, Boyd 1991, 34-35, fig. 4;

\footnotetext{
3 За перекладом В. Ю. Крюкової [Крюкова 2005, 260].

4 За перекладом В. Ю. Крюкової [Крюкова 2012, 176].

5 За перекладом К. Г. Залемана [Авеста... 1997, 121].

${ }^{6}$ Пехл. hāwan. Див.: [Kotwal, Boyd 1991, 34-35, fig. 4; 137].

${ }^{7}$ У перській мові tašt - 'великий таз (металевий), корито' [Рубинчик 1970, I, 373].
} 
Г. В. Вертієнко

138]. До того ж у ритуальній практиці використовується суто металевий посуд [Kotwal, Boyd 1991, 65-67], але чи було так завжди?

Раннім письмовим підтвердженням цієї практики можна назвати Ясну 10.17 , але чи відображає цей текст реальні маніпуляції з посудом з благородних металів або є лише метафорою - сказати складно. Для з'ясування питання звернемося до етимології слова tašta. Воно походить від і.-є. основи *tetḱ- (tekp-), яка має значення ‘створювати, різати, тесати' [Pokorny 1959, 1058]. Від неї походить авест. tašaiti‘теслювати', tāšš $\delta a n$ 'обробляти дерево' і taša- 'сокира'. Це дає підстави розуміти слово tašta- як 'вирізаний/вирубаний (з дерева)'. Від цієї ж і.-є. основи походять санскр. takșati ‘висічений, оброблений, вирізаний’ і takș- 'теслювати’ [Pokorny 1959, 1058-1059]. Останнє дієслово, зокрема, описує дію, характерну для ведичних майстрів-теслярів Рібху. Ці майстри витесали чотири окремі чаші з першої чарівної чаші-camasâ для соми, створеної творцем усіх форм Тваштаром (Tvaștar) (Ригведа (= PB) I.20.6; I.52.7; I.61.6; I.161.5; X.10.5; X.184.1) [McDonell 1897, 116-118; Ammer $1949,68-77]$. Отже, хоча лексика Ригведи донесла цілу низку назв ритуального посуду, пов'язаного зі священним напоєм [MacDonell, Keith 1912, II, 476-477; Топоров, Елизаренкова 2009, 35] (табл. 2), саме дерев'яна чаша для соми camasâ може бути семантично співвіднесена з іранською tašta. У Ригведі camasâ- позначає 'посудину для пиття', 'дерев' яний кубок' і зазвичай використовується для найменування посудини для соми при жертвоприношенні.

Табл. 2. Ритуальний посуд у Ригведі (за [MacDonell, Keith 1912])

\begin{tabular}{|c|c|c|c|}
\hline 1 & camasâ & $\begin{array}{l}\text { “"посудина для пиття”, “дерев’яний ку- } \\
\text { бок”, } \\
\text { “чаша для соми”, створена Тваштаром }\end{array}$ & $\begin{array}{l}\text { I.20.6; I.110.3; I.161.1, 2, 5; III.48.4; } \\
\text { IV.35.2, 3, 5; IV.36.4; VIII.82.7; X.16.81; } \\
\text { X.68.8; X.96.9 }\end{array}$ \\
\hline 2 & camū & “мииска для соми”, “чан”, чаша” & $\begin{array}{l}\text { I.164.33; IX.36.1; IX.69.5; IX.71.1; IX.72.5; } \\
\text { IX.86.47; IX. 96.20, 21; IX.97.2, 48; } \\
\text { IX.103.4; IX.107.10; IX.108.10 } \\
\text { I.28.9; III.76.10; IV.18.3; V.51.4; VI.57.2; } \\
\text { VIII.4.4; IX.46.3; X.24.1; IX.36.1 }\end{array}$ \\
\hline 3 & âmatra & $\begin{array}{l}\text { “велика (безмірна) посудина для пиття } \\
\text { соми” (Індри і Ваю) }\end{array}$ & II.14.1; V.51.4; VI.42.2; X.29.7 \\
\hline 4 & dhisânâ & $\begin{array}{l}\text { вичавлена сома" (метонімічне значен- } \\
\text { ня) }\end{array}$ & 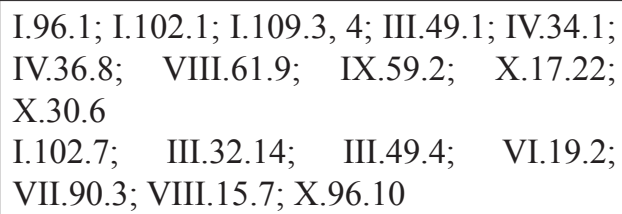 \\
\hline 5 & drôna & $\begin{array}{l}\text { “дерев’яна посудина, чан” (для збері- } \\
\text { гання соми) }\end{array}$ & $\begin{array}{l}\text { VI.2,8; VI.37.2; VI.44.20; IX.3.1; IX.15.7; } \\
\text { IX.28.4; IX.30.4; IX.67.14; IX.93.1 }\end{array}$ \\
\hline 6 & $d r u$ & “дерев’яна посудина” (букв. “дерево”) & $\begin{array}{l}\text { I.161.1; V.86.3; VIII.66.11; IX.1.2; IX.65.6; } \\
\text { IX.98.2 }\end{array}$ \\
\hline 7 & vana & “дерев’яна посудина” (для соми) & $\begin{array}{l}\text { I.54.I; I.65.8; II.14.9; III.51.5; V.41.11; } \\
\text { IX.66.9 }\end{array}$ \\
\hline 8 & pātrā & 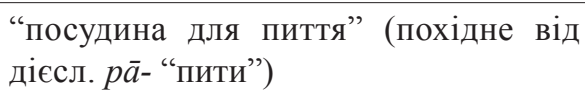 & $\begin{array}{l}\text { I.82.4; I.104.8; I.110.5; I.162.13; VI.27.6; } \\
\text { VII.104.21; VIII.103.6; X.53.9 }\end{array}$ \\
\hline
\end{tabular}


Авестійська чаша-tašta в іранській традиції: витоки та ремінісценції

\begin{tabular}{|c|c|c|c|}
\hline 9 & kalâsa & “"горщик”, “глечик”, “кухоль”, “чаша” & $\begin{array}{l}\text { I.117.12; III.32.15; IV.27.5; IV.32.19; } \\
\text { IX.8.6; IX.12.5; IX.17.4; IX.18.7; IX.67.14; } \\
\text { IX.68.9; IX.84.4; IX.86.6, 9, 35, 47; } \\
\text { IX.96.23 }\end{array}$ \\
\hline 10 & kośa & $\begin{array}{l}\text { “велика посудина” (для соми) } \\
\text { (букв. “відро”) }\end{array}$ & VII.101.4; VIII.20.8; IX.75.3 \\
\hline 11 & $\operatorname{sad}^{h} a_{s} t^{h} a$ & $\begin{array}{l}\text { “посудина” (для соми) } \\
\text { (букв. “місце, будинок, обитель”) }\end{array}$ & III.62.15; IX.1.2; IX.17.8 \\
\hline
\end{tabular}

Археологами робилися спроби пов'язати з індоіранським ритуальним посудом для соми посудини, виявлені в чоловічих похованнях степової зони Євразії бронзового і раннього залізного віку. Використання священного напою в середовищі іраномовних номадів скіфської епохи передусім пов'язують 3 археологічно зафіксованими дерев'яними чашами, нерідко прикрашеними золотими пластинами із зображеннями різних істот (оленя, птаха, риби, грифона, кабана тощо) (мал. 2). Подібні чаші вважають найдавнішою формою ритуального посуду з огляду на те, що в арійській ритуальній культурі використовували суто дерев'яний посуд.

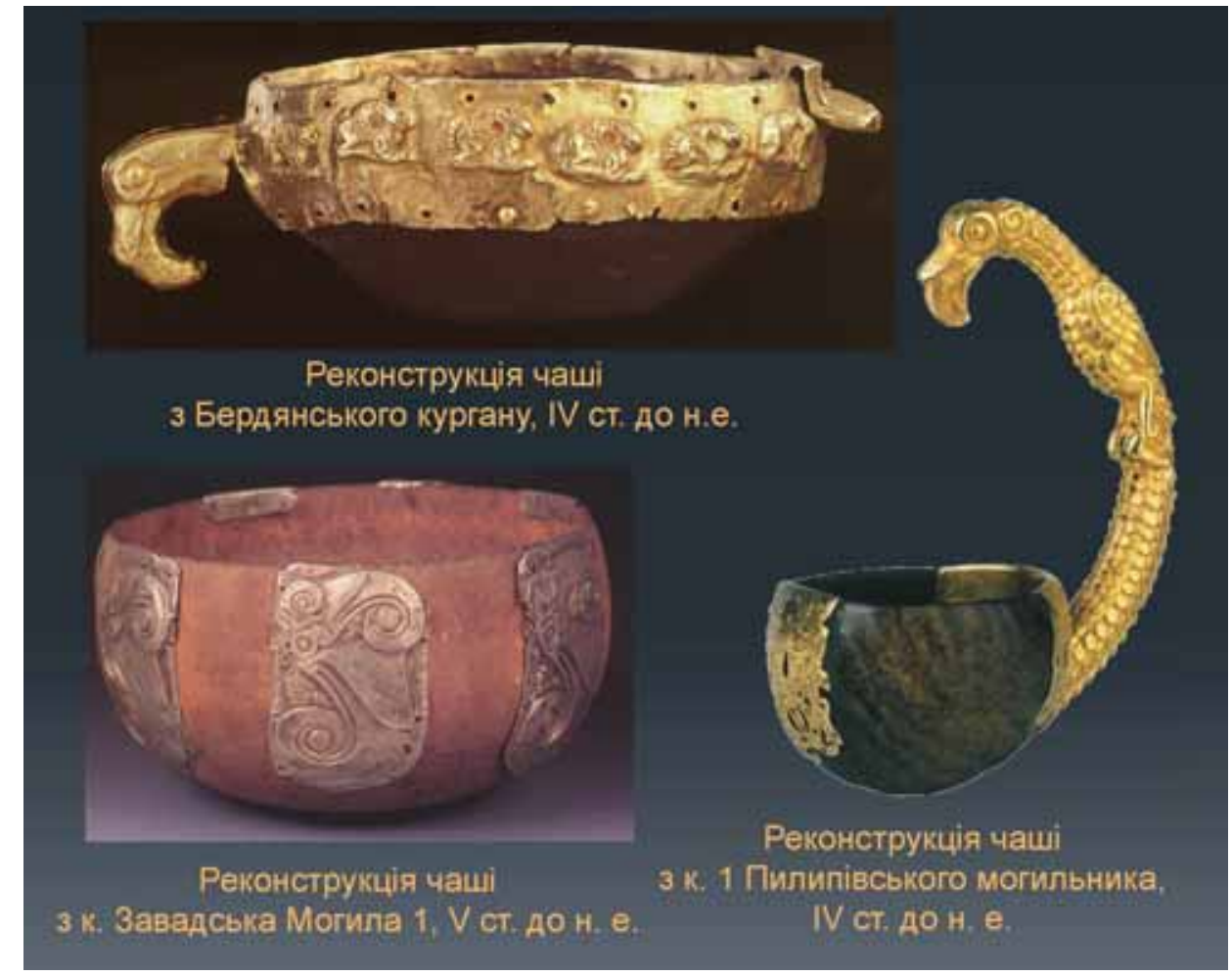

Мал. 2. Зразки скіфських дерев'яних чаш із золотими накладками

Про значення цих дерев'яних чаш склалося кілька гіпотез:

- індикатор жрецьких поховань (за доби бронзи) [Отрощенко 1984, 84-96; 1993, 17; Цимиданов 2004,75-76];

- зв'язок з культом соми [Медведев 1997, 167-168; Федоров 2006, 46-48; Fedorov 2000, 64-65; Кисель 2002, 32-35; 2003, 57-63; 2007, 110-114]; 
- належність дерев'яних чаш до поховань воїнів [Рябова 1984, 31-43; 1989, 136-139] і до символіки доблесті [Фиалко 1980, 92-93; 2004, 269-272; Кузнецова 1993, 73-80];

- зв'язок з весільним обрядом, а через його посередництво - 3 поховальним обрядом [Королькова 2003, 28-59].

Для ілюстрації зв'язку дерев'яних чаш із накладками зрубної культури з культом соми дослідники зверталися до текстів Ригведи (В. В. Отрощенко, О. П. Медведєв, В. К. Федоров, О.О.Дудін, Т. М. Сай). Зокрема, В. В. Отрощенко звертається до IX мандали, у якій нібито йдеться про “ложе” для соми, “оковане залізом” [Отрощенко 1984, 84-96]. Мова йде про це місце (в перекладі Т. Я. Слізаренкової):

"Убийца демонов, известный среди всех народов,

Он сел на (свое) ложе, вытесанное железом,

На (свое) место из дерева" (РВ IX 1.2) [Ригведа 1999, 5].

Втім, тут немає натяку на металеві оббивки чаш для соми, адже $a b^{h}$ y $_{\text {yónim áyo- }}$ hatam має переклад “увійшов у лонов, витесане бронзою/металом”. Сама ж Т. Я. Єлізаренкова, коментуючи це місце, підкреслює, що “здесь подразумевается металлический топор, которым вытесали деревянный сосуд, кажется вполне убедительным" [Ригведа 1999, 256, к. 2b]. А проте спроби знайти вказівки на декорування посуду металом у Ригведі на цьому не полишили, і В. К. Федоров вказав на ще одне місце в мандалі IX [Федоров 2006, 47] (у перекладі Т. Я. Слізаренкової): “...Сверкающий, ты восходишь на место, обитое железом" (РВ IX.80.2) [Ригведа 1999, 71]. 3 думкою В. К. Федорова погоджується О. О. Дудін, вказуючи, що цей пасаж "остается почти единственным указанием на возможное декорирование металлом деревянных сосудов у ведических ариев. К тому же в этом случае речь идет об использовании железа, но никак ни бронзы или меди, что в хронологическом плане очень важно" [Дудин 2015, 21]. Втім, вказана фраза може мати й інший переклад: áyohatam yónim á rohasi dyumán - "на витесане бронзою/металом місце ти, Осяйний, сходиш". Отже, в обох фрагментах тексту вжито те саме компаундне слово áyohata- (ayas+hata) 'витесаний бронзою/металом', яке в першому випадку було перекладене Т. Я. Слізаренковою як “вытесанное железом”, а в другому - як “обитое железом”. Вжите тут санскр. ф́xys- 'метал (некоштовний)' має первинне значення 'бронза', і лише пізніше це слово стали вживати як загальне позначення некоштовних металів [Расторгуева, Эдельман 2000, 146; пор.: Вертієнко 2018, 108 109]. Отже, чи витесана ця чаша бронзовою чи залізною сокирою ніяк не впливає на іiі зовнішню оздобу i, на нашу думку, не може бути підтвердженням існування чаш для соми, оббитих якимось металом.

Також необхідно зазначити, що в індійській традиції дерев'яні чаші використовувалися не тільки в культі соми, а й в інших ритуалах та обрядах. Наприклад, кроплення майбутнього правителя різними видами води, що збиралася в спеціальні дерев'яні посудини, становило суть обряду абгішека - частини коронації ритуалу раджасуя [Heesterman 1957, 91-98; Альбедиль 2015, 51]. Про те, як слід розподіляти жертовні посудини на тілі померлого при поховальному обряді, оповідає "Гіраньякеші-пітримедга-сутра" VI, з якої стає зрозуміло, що з усіх посудин, перерахованих вище і пов'язаних із сомою, в індійській поховальній обрядовості задіяна тільки

\footnotetext{
${ }^{8}$ Тобто yóni-, букв. ‘лоно, дім, місце' - метафора дерев'яної чаші.
} 
Авестійська чаша-tašta в іранській традиції: витоки та ремінісценції

camasâ і розміщується вона посередині тіла небіжчика (імовірно, на грудній клітці) [Пандей 1990, 284].

Повертаючись до проблеми ідентифікації ритуальної посуди іраномовних кочівників Північного Причорномор'я, зазначимо, що в античних джерелах, зокрема в Геродота, згадки скіфського посуду контекстуально диференційовані [Кузнецова 1988, 17-23; 2004, 93-105; Кисель 2003, 57-63; 2007a, 69-79], що демонструє наведена таблиця (табл. 3 ).

Табл. 3. Скіфський культовий посуд за античними джерелами

\begin{tabular}{|c|c|c|c|}
\hline 1 & $\varphi)^{\alpha} \lambda \eta v$ & $\begin{array}{l}\text { Herod., Hist., IV.5.3 } \\
\text { Ibid., IV.7 } \\
\text { Ibid., IV.10.1 } \\
\text { Ibid., IV.10.3 } \\
\text { Ibid., IV.71.4 }\end{array}$ & $\begin{array}{l}\text { - Послана небом як один зі священних дарів, які стали сим- } \\
\text { волом царської влади. } \\
\text { - Об’єкт поклоніння. } \\
\text { - Геракл залишив своєму нащадкові, Скіфу, родоначальни- } \\
\text { ку скіфів. } \\
\text { - Всі скіфи в пам'ять про першопредка носять на поясах. } \\
\text { - Кладуть у царські поховання. }\end{array}$ \\
\hline 2 & $\alpha ̈ \gamma \alpha \lambda \mu \alpha$ & Herod., Hist., IV.26.2 & - Виготовляли з людських черепів. \\
\hline 3 & $\pi \mathrm{o \tau \eta ́ \rho iov}$ & $\begin{array}{l}\text { Herod., Hist., IV.65.1 } \\
\text { Strabo., VII.3.7 }\end{array}$ & $\begin{array}{l}\text { - Виготовляли з людських черепів. } \\
\text { - Разом з мечем - єдина річ в індивідуальній власності скі- } \\
\text { фів. }\end{array}$ \\
\hline 4 & $\kappa \rho \alpha \tau \eta ́ \rho$ & Herod., Hist., IV.66.1 & $\begin{array}{l}\text { - Під час щорічного обрядового вшанування відваги воїнів } \\
\text { у номарха наповнювався вином. }\end{array}$ \\
\hline 5 & $\kappa v ́ \lambda 1 \xi$ & $\begin{array}{l}\text { Herod., Hist., IV.66.1 } \\
\text { Ibid., IV, } 70 \\
\text { Luc., Tox., } 37\end{array}$ & $\begin{array}{l}\text { - П’ють воїни під час згаданого свята вшанування відваги. } \\
\text { - Використовується при воїнському обряді “братання”. }\end{array}$ \\
\hline 6 & 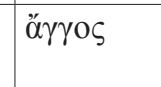 & Herod., Hist., IV.62.3 & $\begin{array}{l}\text { - Посудина, куди збирають кров жертв-полонених під час } \\
\text { ритуального вшанування “Ареса”. }\end{array}$ \\
\hline
\end{tabular}

3 наведеного матеріалу можна зробити висновок, що Геродот позначав культовий посуд, який скіфи використовували в обрядовій сфері і який мав особливий

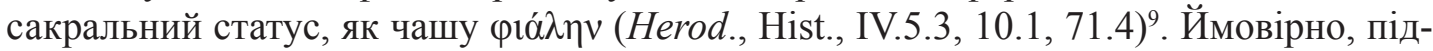
ставою для цього зіставлення були як схожість за зовнішнім виглядом, так і ритуальний характер чаш-фіал в еллінській культурі [Liddell, Scott 1996, 1930]. Решта видів чаш і посуду або застосовувалися у сфері воїнських ритуалів (клятва, жертвопринесення “Аресові”, вшанування доблесті воїнів), або були задіяні в культі черепів. Саме чаші-фіали як пам'ять про першого царя, за Геродотом, скіфи носили на поясах (Herod., Hist., IV.10.3), а видом посуду, який археологічно зафіксований на поясах у похованнях кочівників скіфської епохи, є дерев'яні чаші з металевими накладками. Це підтверджується знахідками в таких комплексах: Бердянський курган (кін. V - поч. IV ст. до н. е.) [Мурзин, Белан, Подвысоцкая 2017, 36; 76, рuс. 23], курган № 15 могильника Доге-Баари 2 (Тува, VI-V ст. до н. е.) [Чугунов 1996, 72],

9 У генеалогічних легендах фігурує фió $\eta v$, яка була послана небом як один зі священних дарів, що стали символом царської влади (Herod., Hist., IV.5.3) та об'єктом поклоніння (Herod., Hist., IV.7). Золоту чашу-фı́́ $\eta v$ Геракл залишив своєму нащадкові Скіфу, родоначальнику скіфів (Herod., Hist., IV.10.1), i, як пише Геродот, “через цю чашу скіфи й понині носять чаші на поя-

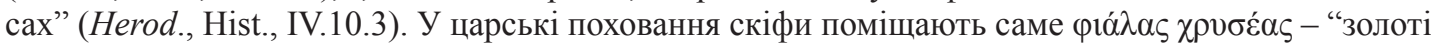
фіали" (Herod., Hist., IV.71.4). 
курган № 10 поховання № 1 Переволочанського могильника (Південний Урал) i, можливо, Великий Полтаківський курган (Південний Сибір) [Королькова 2003, 34, 36].

Підводячи підсумок, зазначимо, що саме чаша-tašta, за авестійськими джерелами, виступає зброєю як жерців, так і Заратуштри (Відевдат 14.8; 19.9). Вона призначена для узливань (Вісперад $10.2=11.18$ ) і є чашею для хаоми (Відевдат 14.8; Ясна 10.17). Ясна 10.17 допускає в ритуалі приготування хаоми срібні і золоті чаші. Доволі широкий спектр матеріалів, з яких вона могла бути зроблена, дає Відевдат 7.73-75: золото, срібло, бронза, залізо, камінь, земля, дерево і глина. За етимологією tašta входила в початкове індоєвропейське семантичне коло предметів, виготовлених $з$ дерева. Тобто у стародавньому Ірані ритуальна чаша-tašta, ймовірно, була дерев'яною.

Ведична традиція зберегла різні назви посуду, пов'язаного з культом соми. Об'єднує його матеріал виготовлення - дерево. 3 усього спектра відомих лексем найбільш семантично виправданою назвою чаші для узливань $є$ camasâ, яка була створена як перша чудова чаша для соми божественним теслярем, творцем усіх

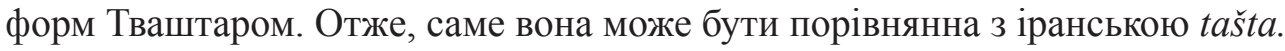

Якщо інтерполювати дані індоіранської писемної традиції на археологію ранніх іраномовних кочівників Свразії, то найбільш близькими до tašta і camasâ будуть дерев'яні чаші з металевими накладками, відомими в Північному Причорномор'ї вже $з$ доби бронзи (зрубна культура). У цьому кочовому середовищі, віддаленому від Індії й Ірану, імовірно, відбулися певні зміни в культі хаоми, що виявилися у традиції декорування дерев'яних чаш металевими (бронза, срібло, золото) пластинами. Геродот визначав ритуальні чаші у скіфів як фió $\lambda \eta v$, що можна зіставити 3 типологічно схожими скіфськими дерев'яними чашами 3 оббивками місцевого виробництва. Використання імпортного посуду, імовірно, для потреб культу священного напою було неприпустимим.

\section{ЛІТЕРАТУРА}

Авеста в русских переводах (1861-1996) / Сост., общ. ред., примеч., справ. разд. И. В. Рак. Санкт-Петербург, 1997.

Альбедиль М. Ф. Символические формы проявления царской власти в Древней Индии // Реальные и знаковые формы социальной дифференциации в архаике. Миф и формы его отражения в ритуальной практике / Под ред. М. Ф. Альбедила, Д. Г. Савинова (Теория и методология архаики. Вып. VIII). Санкт-Петербург, 2015.

Вертієнко Г. В. До питання про метал в Авесті // Стародавнс Причорномор'я / Ред. І. В. Нємченко. Вип. ХІІ. Одеса, 2018.

Дудин А. А. Культ Сомы и археологические реалии в степях Восточной Европы в первой трети I тыс. до н. э. // Актуальні проблеми вітчизняної та всесвітньої історії. 2015. № 13.

Кисель B. A. Келермесский сосуд и сакральный напиток скифов // Ладога и Северная Евразия от Байкала до Ла-Манша. Связующие пути и организующие центры. Шестые чтения памяти Анны Мачинской (Старая Ладога, 21-23 декабря 2001 г.). Санкт-Петербург, 2002. 
Авестійська чаша-tašta в іранській традиції: витоки та ремінісценції

Кисель В. А. Ритуальные сосуды и напитки скифов // Степи Евразии в древности и средневековье. К 100-летию со дня рождения М. П. Грязнова / Ред. Ю. Ю. Пиотровский. Т. ІІ. Санкт-Петербург, 2003.

Кисель B. A. “Огненный” напиток скифов // Сборник научных трудов в честь 60-летия А. В. Виноградова / Ред. С. В. Хаврин. Санкт-Петербург, 2007.

Кисель B. А. Рассказ Геродота и ритуальные сосуды древних кочевников // Aрхеология, этнография и антропология Евразии. 2007a. № 3 (31).

Королькова $E$. Ф. Ритуальные чаши с зооморфным декором в культуре ранних кочевников // Археологический сборник Государственного Эрмитажа. Вып. 36. Санкт-Петербург, 2003.

Крюкова В. Ю. Зороастризм. Санкт-Петербург, 2005.

Крюкова В. Ю. Восстановление утраченного мира как искупительная жертва (Видевдат 14) // Жертвоприношение в архаике: атрибуция, назначение, цель / Ред. М. Ф. Альбедиль, Д. Г. Савинова. Санкт-Петербург, 2012.

Кузнецова Т. М. Сосуды скифов в "Истории" Геродота // Археологические памятники раннего железного века Юга России. Москва, 2004.

Кузнецова Т. М. "Поти́рıо" Скифского логоса Геродота // Петербургский археологический вестник. 1993. № 4.

Кузнецова Т. М. Скифские ритуальные сосуды // Краткие сообщения Института археологии РАН. 1988. № 194.

Медведев А. П. Об атрибуции “жреческих” погребений у ираноязычных номадов III - I тысячелетий до н. э. // Исторические записки. 1997. № 2.

Мурзин В. Ю., Белан Ю. А., Подвысоикая Е. П. Бердянский курган. (Погребальный комплекс скифского аристократа IV в. до н. э.). Киев, 2017.

Отрощенко В. В. Деревянная посуда в срубных погребениях Поднепровья // Проблемы археологии Поднепровья. Днепропетровск, 1984.

Отрощенко В. В. “Жреческие” комплексы в системе погребений срубной общности // Археологічні та історичні дослідження Херсонщини. Херсон, 1993.

Пандей Р. Б. Древнеиндийские домашние обряды (обычаи). Москва, 1990.

Расторгуева В. С., Эдельман Д. И. Этимологический словарь иранских языков. Т. 1: a-̄a. Москва, 2000.

Ригведа. Мандалы IX-X / Пер. с санскр. Т. Я. Елизаренковой. Москва, 1999.

Рубинчик Ю. А. Персидско-русский словарь. Т. 1-2. Москва, 1970.

Рябова В. О. Дерев'яні чаші з оббивками з курганів Скіфського часу // Археологія. 1984. № 46.

Рябова B. А. Ритуальные сосуды как источник социально-политической истории Скифии // Тезисы докладов областной конференции "Проблемы скифо-сарматской археологии Северного Причерноморья", посвященной 90-летию со дня рождения Б. Н. Гракова. Запорожье, 1989.

Топоров В. Н., Елизаренкова Т. Я. Ведийский “вещный” космос (“Слова и вещи”: язык как источник реконструкции мира вещей) // Топоров В. Н. Исследования по этимологии и семантике. Т. 3: Индийские и иранские языки. Кн. 1. Москва, 2009.

Федоров В. K. О предназначении деревянных сосудов ранних кочевников Южного Урала, украшенных драгоценными обкладками // Южный Урал и сопредельные территории в скифо-сарматское время. Сборник статей к 70-летию Анатолия Харитоновича Пшеничнюка / Отв. ред. Н. С. Савельев. Уфа, 2006. 
Фиалко Е. Е. О культовом назначении деревянных чаш // Археологические исследования на Украине в 1978-79 гг. Тезисы докладов XVIII конференции ИА АН УССР / Отв. ред. В. Ф. Генинг. Днепропетровск, 1980.

Фиалко E. E. Деревянные чаши - знак воинской доблести у скифов // Старожитності степового Причорномор'я і Криму. Вип. ХІ. Запоріжжя, 2004.

Цимиданов В. В. Социальная структура срубного общества. Донецк, 2004.

Чугунов $K . B$. Археологические параллели одному изобразительному мотиву в искусстве ранних кочевников Евразии // Номадизм - прошлое, настоящее в глобальном контексте и исторической перспективе. Тезисы конференции. УланУдэ, 1996.

Ammer K. Tvașțar, ein altindischer Schöpfergott// Die Sprache. Zeitschrift für Sprachwissenschaft. 1949 . Bd. 1.

Bartholomae Chr. Altiranisches Wörterbuch. Strassburg, 1904.

Fedorov V. Bone Spoons and Wooden Vessels of the Nomads and the Cult of Soma/ Hauma // The Golden Deer of Eurasia. Scythian and Sarmatian Treasures from the Russian Steppes. Ufa - New York, 2000.

Flattery D. S., Schwartz M. Haoma and Harmaline the Botanical Identity of the Indo-Iranian Sacred Hallucinogen Soma and its Legacy in Religion, Language, and Middle-Eastern Folklore (University of California Publications. Near Eastern Studies. Vol. 21). Berkeley - New York - London, 1988.

Heesterman J. C. The Ancient Indian Royal Consecration: the Rājasūya described according to the Yajus texts and annotated. Mouton, 1957.

Kellens J. Haoma // Dictionary of Deities and Demons in the Bible. Leiden, 1995.

Kotwal F., Boyd J. A Persian Offering. The Yasna, a Zoroastrian High Liturgy (Studia Iranica. T. 8). Paris, 1991.

Liddell H. G., Scott R. A Greek-English Lexicon. Oxford, 1996.

McDonell A. A. Vedic Mythology (Grundriss der Indo-Arischen Philologie und Altertumskunde. Bd. III, Hft. 1). Strassburg, 1897.

MacDonell A. A., Keith A. B. Vedic Index of Names and Subjects. Vol. I-II. London, 1912.

Pokorny J. Indogermanisches etymologisches Wörterbuch. Bern - München, 1959.

Schwartz M. On Haoma, and its Liturgy in the Gathas // Proceedings of the $5^{\text {th }}$ Conference of the Societas Iranologica Europoa held in Ravenna, 6-11 October 2003. Vol. I: Ancient \& Middle Iranian Studies / Ed. by A. Panaino, A. Piras. Milan, 2006.

\section{REFERENCES}

Avesta $v$ russkikh perevodakh (1861-1996) (1997), ed. and preface I. V. Rak, Zhurnal "Neva" and RKHGI, Saint Petersburg. (In Russian).

Albedil M. F. (2015), "Cimvolicheskiye formy proyavleniya tsarskoy vlasti v Drevney Indii", in M. F. Albedil and D. G. Savinov (eds), Realnyye i znakovyye formy sotsialnoy differentsiatsii $v$ arkhaike. Mif $i$ formy ego otrazheniya $v$ ritualnoy praktike, Teoriya $\mathrm{i}$ metodologiya arkhaiki, Vyp. VIII, MAE RAN, Saint Petersburg, pp. 47-54. (In Russian).

Vertiienko H. V. (2018), "Do pytannya pro metal v Avesti”, in I. V. Nemchenko (ed.), Starodavnye Prychornomorya, Vyp. XII, ONU im. I. I. Mechnikova, Odesa, pp. 108-16. (In Ukrainian). 
Dudin A. A. (2015), "Kult Somy i arkheologicheskiye realii v stepyakh Vostochnoy Evropy v pervoy treti I tys. do n. e.”, Aktual'ni problemy vitchyznyanoyi ta vsesvitnoyi istoriyi, No. 13, pp. 15-23. (In Russian).

Kisel V. A. (2002), "Kelermesskiy sosud i sakralnyy napitok skifov", in Ladoga $i$ Severnaya Evraziya ot Baykala do La-Mansha. Svyazuyushchiye puti i organizuyushchiye tsentry. Shestyye chteniya pamyati Anny Machinskoy (Staraya Ladoga, 21-23 dekabrya 2001 g.), Staroladozhskiy istoriko-arkhitekturnyy i arkheologicheskiy muzey-zapovednik, Saint Petersburg, pp. 72-8. (In Russian).

Kisel V. A. (2003), "Ritualnyye sosudy i napitki skifov", in Yu. Yu. Piotrovskiy (ed.), Stepi Evrazii v drevnosti i srednevekovye. K 100-letiyu so dnya rozhdeniya M. P. Gryazno$v a$, Vol. II, Izd-vo Gos. Ermitazha, Saint Petersburg, pp. 57-63. (In Russian).

Kisel V. A. (2007), “'Ognennyy' napitok skifov”, in S. V. Khavrin (ed.), Sbornik nauchnykh trudov v chest 60-letiya A. V. Vinogradova, Kult-Inform-Press, Saint Petersburg, pp. 110-4. (In Russian).

Kisel V. A. (2007a), "Rasskaz Herodota i ritual'nyye sosudy drevnikh kochevnikov", Arkheologiya, etnografiya i antropologiya Evrazii, Vol. 3 (31), pp. 69-79. (In Russian).

Korolkova E. F. (2003), "Ritualnyye chashi s zoomorfnym dekorom v kulture rannikh kochevnikov", Arkheologicheskiy sbornik Gosudarstvennogo Ermitazha, Vol. 36, pp. 28-59. (In Russian).

Kryukova V. Yu. (2005), Zoroastrizm, Azbuka, Saint Petersburg. (In Russian).

Kryukova V. Yu. (2012), "Vosstanovleniye utrachennogo mira kak iskupitelnaya zhertva (Videvdat 14), in M. F. Albedil and D. G. Savinova (eds), Zhertvoprinosheniye v arkhaike: atributsiya, naznacheniye, tsel', MAE RAN, Saint Petersburg, pp. 166-78. (In Russian).

Kuznetsova T. M. (1988), "Skifskiye ritualnyye sosudy", Kratkiye soobshcheniya instituta arkheologii RAN, T. 194, pp. 17-23. (In Russian).

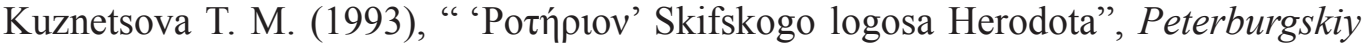
arkheologicheskiy vestnik, No. 4, pp. 73-80. (In Russian).

Kuznetsova T. M. (2004), "Sosudy skifov v 'Istorii' Gerodota", in Arkheologicheskiye pamyatniki rannego zheleznogo veka Yuga Rossii, Izd-vo IA RAN, Moscow, pp. 93105. (In Russian).

Medvedev A. P. (1997), “Ob atributsii 'zhrecheskikh' pogrebeniy u iranoyazychnykh nomadov III-I tysyacheletiy do n. e.”, Istoricheskiye zapiski, No. 2, pp. 165-71. (In Russian).

Murzin V. Yu., Belan, Yu. A. and Podvysotskaya E. P. (2017), Berdyanskiy kurgan. (Pogrebalnyy kompleks skifskogo aristokrata IV v. do n. e.), Vidavets Oleg Filyuk, Kyiv. (In Russian).

Otroshchenko V. V. (1984), "Derevyannaya posuda v srubnykh pogrebeniyakh Podneprovya", in Problemy arkheologii Podneprovya, Izd-vo DGU, Dnepropetrovsk: pp. 8497. (In Russian).

Otroshchenko V. V. (1993), “' 'Zhrecheskiye' kompleksy v sisteme pogrebeniy srubnoy obshchnosti”, in Arkheologichni ta istorichni doslidzhennya Khersonshchiny, Kherson, pp. 17-31. (In Russian).

Pandey R. B. (1990), Drevneindiyskiye domashniye obryady (obychai), Vysshaya shkola, Moscow. (In Russian).

Rastorguyeva V. S. and Edelman D. I. (2000), Etimologicheskiy slovar iranskikh yazykov, Vol. 1: a-ā. Izdatelskaya firma "Vostochnaya literatura" RAN, Moscow. (In Russian). 
Г. В. Вертієнко

Rigveda. Mandaly IX-X (1999), Per. s sanskr. T. Ya. Elizarenkovoy, Nauka, Moscow. (In Russian).

Rubinchik Yu. A. (1970), Persidsko-russkiy slovar', Vol. 1-2, Russkiy yazyk, Moscow. (In Russian).

Ryabova V. O. (1984), "Derev'yani chashy z obbivkamy z kurganiv Skifs'koho chasu", Arheologia, No. 46, pp. 31-43. (In Ukrainian).

Ryabova V. A. (1989), "Ritualnyye sosudy kak istochnik sotsialno-politicheskoy istorii Skifii", in Tezisy dokladov oblastnoy konferentsii "Problemy skifo-sarmatskoy arkheologii Severnogo Prichernomorya", posvyashchennoy 90-letiyu so dnya rozhdeniya B. N. Grakova, Vydavnytstvo Zaporiz'koho Natsionalnogo Universitetu, Zaporozhye, pp. 136-9. (In Russian).

Toporov V. N. and Elizarenkova T. Ya. (2009), "Vediyskiy 'veshchnyy' kosmos ('Slova i veshchi': yazyk kak istochnik rekonstruktsii mira veshchey)”, in V. N. Toporov, Issledovaniya po etimologii i semantike, Vol. 3: Indiyskiye i iranskiye yazyki, Book 1, Yazyki slavyanskikh kultur, Moscow, pp. 7-89. (In Russian).

Fedorov V. K. (2006), "O prednaznachenii derevyannykh sosudov rannikh kochevnikov Yuzhnogo Urala, ukrashennykh dragotsennymi obkladkami”, in N. S. Savelyev (ed.), Yuzhnyy Ural i sopredelnyye territorii v skifo-sarmatskoye vremya. Sbornik statey $k$ 70-letiyu Anatoliya Kharitonovicha Pshenichnyuka, Izd-vo “Gelem”, Ufa, pp. 46-57. (In Russian).

Fialko E. E. (1980), "O kultovom naznachenii derevyannykh chash", in V. F. Gening (ed.), Arkheologicheskiye issledovaniya na Ukraine v 1978-79 gg. Tezisy dokladov XVIII konferentsii IA AN USSR, Dnepropetrovskiy Gosudarstvennyy universitet, Dnepropetrovsk, pp. 92-3. (In Russian).

Fialko E. E. (2004), "Derevyannyye chashi - znak voinskoy doblesti u skifov", in Starozhitnosti stepovogo Prichornomorya i Krimu, Vol. XI, Vydavnytstvo Zaporiz'koho Natsionalnogo Universitetu, Zaporizhzhya, pp. 269-72. (In Russian).

Chugunov K. V. (1996), “Arkheologicheskiye paralleli odnomu izobrazitel'nomu motivu v iskusstve rannikh kochevnikov Evrazii", in Nomadizm - proshloye, nastoyashcheye $v$ globalnom kontekste $i$ istoricheskoy perspektive. Tezisy konferentsii, Ulan-Ude, pp. 86-9. (In Russian).

Tsimidanov V. V. (2004), Sotsial'naya struktura srubnogo obshchestva, IA NANU, Donetsk. (In Russian).

Ammer K. (1949), "Tvașțar, ein altindischer Schöpfergott”, Die Sprache. Zeitschrift für Sprachwissenschaft, Bd. 1, pp. 68-77.

Bartholomae Chr. (1904), Altiranisches Wörterbuch, K. J. Trübner, Strassburg.

Fedorov V. (2000), "Bone Spoons and Wooden Vessels of the Nomads and the Cult of Soma/Hauma", in The Golden Deer of Eurasia. Scythian and Sarmatian Treasures from the Russian Steppes. The State Hermitage, Saint-Petersburg, and the Archaeological Museum, Metropolitan Museum of Art \& Yale University Press, Ufa and New York, pp. 65-8.

Flattery D. S. and Schwartz M. (1988), Haoma and Harmaline the Botanical Identity of the Indo-Iranian Sacred Hallucinogen Soma and its Legacy in Religion, Language, and Middle-Eastern Folklore, University of California Publications. Near Eastern Studies, 21, University of California Press, Berkeley, New York and London.

Heesterman J. C. (1957), The Ancient Indian Royal Consecration: the Räjasūya described according to the Yajus texts and annotated, Mouton, La Haye. 
Авестійська чаша-tašta в іранській традиції: витоки та ремінісценції

Kellens J. (1995), "Haoma", in Dictionary of Deities and Demons in the Bible, Brill, Leiden, pp. 729-31.

Kotwal F. and Boyd J. (1991), A Persian Offering. The Yasna, a Zoroastrian High Liturgy, Studia Iranica, 8, Association pour l'avancement des études iraniennes, Paris.

Liddell H. G. and Scott R. (1996), A Greek-English Lexicon, Oxford University Press, Oxford.

McDonell A. A. (1897), Vedic Mythology, Grundriss der Indo-Arischen Philologie und Altertumskunde, Bd. III, Hft. 1, Verlag von Karl J. Trübiner, Strassburg.

MacDonell A. A. and Keith A. B. (1912), Vedic Index of Names and Subjects, Vol. I-II, John Murray, London.

Pokorny J. (1959), Indogermanisches etymologisches Wörterbuch, Francke Verlag, Bern and München.

Schwartz M. (2006), "On Haoma, and its Liturgy in the Gathas", in A. Panaino and A. Piras (eds), Proceedings of the $5^{\text {th }}$ Conference of the Societas Iranologica Europoea held in Ravenna, 6-11 October 2003, Vol. I: Ancient \& Middle Iranian Studies, Mimesis, Milan, pp. 215-24.

\section{Г. У. Вериіенка \\ АВЕСЦЙСКАЯ ЧАША-ТАร̌ТА Ў ІРАНСКАЙ ТРАДЫЦЫІ: ВЫТОКІ ДЫ РЭМІНІСЦЭНЦЫІ}

У зараастрыйскай традыцыі рытуальнай чашай для ўзлівання выступае tašta (Вісперад $10.2=11.18$ ). Яна з'яўляецца чашаю для хаомы (Відэўдат 14.8; Ясна 10.17 ), у сувязі з чым выступае як атрыбут-зброя жрэцтва і Заратуштры (Відэўдат 14.8; 19.9). Дастаткова шырокі спектр матэрыялаў, з якіх яна магла быць зроблена, дае Відэўдат 7.73 - 75: золата, срэбра, бронза (жалеза), сталь (?), зямля (?), дрэва і гліна, прычым тры апошнія віды чашаў не паддаюцца ачышчэнню. Ясна 10.17 дапускае ў рытуале прыгатавання хаомы срэбныя ды залатыя чашы. Згодна этымалогіi, tašta ўваходзіць у пачатковае індаеўрапейскае семантычнае кола рэчаў, зробленых (вычасаных) 3 дрэва. Нягледзячы на тое, што ведычная традыцыя зберагла шэраг назваў драўлянага посуду, звязаных з культам сомы (у тым ліку метафарычныя назвы), са старажытнаіранскаю tašta, напэўна, можа быць суаднесена толькі camasâ першая чароўная драўляная чаша для сомы, вычасаная боскім цесляром Тваштарам (РВ I.20.6). У ранніх іранамоўных качэўнікаў Еўразіі найбольш блізкімі да tašta і camasâ могуць быць драўляныя чашы 3 металічнымі (залатымі, срэбнымі і бронзавымі) накладкамі, якія вядомы ў Паўночным Прычарнамор'і ўжо з эпохі бронзы (зрубная культура). У асяродку іранамоўных намадыстаў Еўразіі, аддаленых ад Індыі і Ірану, верагодна, як следства міграцыйных працэсаў, склалася самабытная традыцыя ўпрыгожвання металёвымі пласцінамі драўляных культавых чаш для ўзлівання, якая паядноўвае ў сабе рысы індыйскай і іранскай традыцыі. Магчыма, гэты тып посуду меў на ўвазе Герадот, які адзначыў рытуальныя чашы y̆ скіфаў, як фıа́ $\eta$ v (Herod., Hist., IV.5.3, 10.1, 71.4), то бок, як тыпалагічна падобны посуд. Пры тым, у скіфаў выкарыстанне імпартных чаш для патрэб культу свяшчэннага напою, відавочна, было недапушчальным.

Ключавыя словы: Іран, зараастрыйская традыцыя, Авеста, рытуал, чаша для ўзлівання, tašta, haoma

\section{Г. В. Вертієнко \\ АВЕСТІЙСЬКА ЧАША-ТАS̆ТА В ІРАНСЬКІЙ ТРАДИЦІї: ВИТОКИ ТА РЕМІНІСЦЕНЦІї}

У зороастрійській традиції ритуальною чашею для узливання виступає tašta (Вісперад $10.2=11.18)$. Вона $€$ чашею для хаоми (Відевдат 14.8; Ясна 10.17), внаслідок чого стає атрибутом-зброєю як жерців, так і Заратуштри (Відевдат 14.8; 19.9). Досить широкий 
спектр матеріалів, з яких вона могла бути виготовлена, дає Відевдат 7.73-75: золото, срібло, бронза (залізо), сталь (?), камінь, земля (?), дерево та глина, причому три останні види чаш не піддаються очищенню. Ясна 10.17 допускає в ритуалі приготування хаоми срібні та золоті чаші. За етимологією tašta входить у первісне індоєвропейське семантичне коло речей, виготовлених (витесаних) 3 дерева. Незважаючи на те що ведична традиція зберегла низку назв дерев'яних посудин, пов'язаних з культом соми (зокрема й метафоричні назви), з давньоіранською tašta, ймовірно, може бути порівняна лише camasâ - перша чарівна дерев'яна чаша для соми, виготовлена божественним теслярем Тваштаром (PB I.20.6). У ранніх іраномовних кочівників Євразії найбільш близькими до tašta і camasâ можуть бути визнані дерев'яні чаші з металевими (золотими, срібними та бронзовими) накладками, які відомі в Північному Причорномор'ї вже з епохи бронзи (зрубна культура). У середовищі іраномовних номадів Євразії, віддалених від Індії й Ірану внаслідок міграційних процесів, імовірно, склалася самобутня традиція декорування металевими пластинами дерев'яних культових чаш для узливання, яка поєднує в собі риси індійської та іранської традицій. Можливо, цей

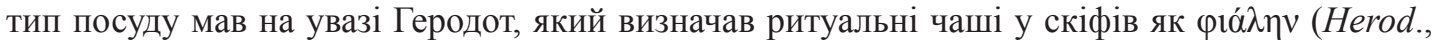
Hist., IV.5.3, 10.1, 71.4), тобто як типологічно схожий посуд. Водночас у скіфів використання імпортних чаш для потреб культу священного напою, вочевидь, було неприпустимим.

Ключові слова: Іран, зороастрійська традиція, Авеста, ритуал, чаша для узливання, tašta, haoma 